\title{
Acinetobacter parvus sp. nov., a small-colony- forming species isolated from human clinical specimens
}

\author{
Alexandr Nemec, ${ }^{1}$ Lenie Dijkshoorn, ${ }^{2}$ Ilse Cleenwerck, ${ }^{3}$ Thierry De Baere, ${ }^{4}$ \\ Danielle Janssens, ${ }^{3}$ Tanny J. K. van der Reijden, ${ }^{2}$ Petr Ježek ${ }^{5}$ \\ and Mario Vaneechoutte ${ }^{4}$ \\ ${ }^{1}$ National Institute of Public Health, Šrobárova 48, 10042 Prague, Czech Republic \\ ${ }^{2}$ Department of Infectious Diseases, Leiden University Medical Center C5-P, P.O. Box 9600, \\ 2300 RC Leiden, The Netherlands \\ ${ }^{3}$ BCCM/LMG Bacteria Collection, University of Ghent, K. L. Ledeganckstraat 35, B-9000 Gent, \\ Belgium \\ ${ }^{4}$ Department of Clinical Chemistry, Microbiology and Immunology, University Hospital, Blok A, \\ B-9000 Gent, Belgium \\ ${ }^{5}$ Department of Clinical Microbiology, U nemocnice 85, Př́bram, Czech Republic
}

Correspondence Alexandr Nemec anemec@szu.cz
The genus Acinetobacter comprises non-motile, strictly aerobic, oxidase-negative, Gram-negative bacteria that grow well on simple media. Twenty-four (genomic) species are currently recognized within the genus (Bouvet \& Grimont, 1986; Tjernberg \& Ursing, 1989; Bouvet \& Jeanjean, 1989; Gerner-Smidt \& Tjernberg, 1993; Vaneechoutte et al., 1999; Nemec et al., 2001) and strains of these species usually form colonies of $1 \cdot 0-2 \cdot 0 \mathrm{~mm}$ in diameter after $24 \mathrm{~h}$ incubation under optimum growth conditions (Bouvet \& Grimont, 1986; Nemec et al., 2001). In a taxonomic study of Acinetobacter clinical isolates (Nemec et al., 2000), two strains were found which formed notably small colonies on routine agar media and could not be identified as any known (genomic) species. These strains were glucose-non-acidifying, non-proteolytic, did not utilize any of the 14 carbon sources of the identification scheme of Bouvet \& Grimont (1987)

Published online ahead of print on 20 June 2003 as DOI 10.1099/ ijs.0.02631-0.

Abbreviation: ARDRA, amplified rDNA restriction analysis.

The EMBL accession numbers for the $16 \mathrm{~S}$ rRNA gene sequences of Acinetobacter parvus LMG $21765^{\top}$ and LMG 21766 are AJ293691 and AJ293690, respectively. and had highly similar amplified rDNA restriction analysis (ARDRA) profiles. Later, five strains similar to the two strains were found among archive strains in our collections. The aim of the present study was to define the taxonomic status of these strains by a polyphasic analysis.

The seven strains used in this study are listed in Table 1. All had the properties of the genus Acinetobacter (Juni, 1984), i.e. they were Gram-negative, strictly aerobic, oxidasenegative, non-motile coccobacilli, and were positive in the transformation assay of Juni (1972). The methods for genotypic characterization included ARDRA, AFLP fingerprinting and comparative 16S rDNA sequence analysis. Phenotypic characterization was done essentially according to Bouvet \& Grimont (1987) and Gerner-Smidt et al. (1991), with some modifications. Details of the methods and their interpretative criteria have been given by Dijkshoorn et al. (1998) and Nemec et al. $(2000,2001)$. The assimilation tests were performed in tubes containing the fluid medium of Cruze et al. (1979) supplemented with $0 \cdot 1 \%(\mathrm{w} / \mathrm{v})$ carbon source. Results were read after 2, 6 and 10 days incubation at $30^{\circ} \mathrm{C}$.

High-molecular-mass DNA for determination of the $G+C$ 
Table 1. Strains of Acinetobacter parvus used in this study

CCM, Czech Collection of Microorganisms, Brno, Czech Republic; LMG, Bacteria Collection, Laboratorium voor Microbiologie Gent, Gent, Belgium; LUH and RUH, Collection L. Dijkshoorn, Leiden University Medical Center, Leiden, The Netherlands; NIPH, Collection A. Nemec, National Institute of Public Health, Prague, Czech Republic; CZ, Czech Republic; NL, The Netherlands.

\begin{tabular}{|c|c|c|c|c|}
\hline $\begin{array}{l}\text { Strain } \\
\text { designation }\end{array}$ & Other strain designation & $\begin{array}{l}\text { Reference/received } \\
\text { from }\end{array}$ & Specimen & $\begin{array}{l}\text { Location and year } \\
\text { of isolation }\end{array}$ \\
\hline LMG $21765^{\mathrm{T}}$ & LUH $4616^{\mathrm{T}}=\mathrm{NIPH} 384^{\mathrm{T}}=\mathrm{CCM} 7030^{\mathrm{T}}$ & Nemec et al. (2000) & Ear (outpatient) & Př́bram, CZ, 1996 \\
\hline LUH 3067 & - & A. T. Bernards & Forehead (inpatient) & Enschede, NL, 1995 \\
\hline LMG 21766 & LUH 3313 & Bernards et al. (1997) & Skin (inpatient) & Leiden, NL, 1995 \\
\hline LUH 7036 & V0102891 & J. Wagenaar & Ear $(\operatorname{dog})$ & Leiderdorp, NL, 2001 \\
\hline
\end{tabular}

content and for DNA-DNA hybridization was prepared from cells grown aerobically on Tryptone Soya Agar (TSA; Oxoid) at $28^{\circ} \mathrm{C}$ by the method of Wilson (1987), with minor modifications. Strains Acinetobacter haemolyticus LMG 996 ${ }^{\mathrm{T}}$, Acinetobacter baumannii LMG $1041^{\mathrm{T}}$, Acinetobacter calcoaceticus LMG $1046^{\mathrm{T}}$ and 'Acinetobacter venetianus' LMG 19082, which produced large amounts of exopolysaccharides, were subjected to a mild alkaline hydrolysis step before cell lysis, as described by Willems et al. (2001). The $\mathrm{G}+\mathrm{C}$ content of the DNA was determined by HPLC according to the method of Mesbah et al. (1989). Nonmethylated phage $\lambda$ DNA (Sigma) was used as the calibration reference. DNA-DNA hybridizations were performed using a modification of the microplate method described by Ezaki et al. (1989) and Goris et al. (1998). Hybridizations were performed at $37^{\circ} \mathrm{C}$ in a hybridization solution $[2 \times$ SSC, $5 \times$ Denhardt's solution, $50 \%(\mathrm{v} / \mathrm{v})$ formamide, $2 \cdot 5 \%$ $(\mathrm{w} / \mathrm{v})$ dextran sulfate, low-molecular-mass denatured salmon sperm DNA to a final concentration of $100 \mu \mathrm{g} \mathrm{ml}^{-1}$, $1 \cdot 25 \mu \mathrm{g}$ biotinylated probe DNA $\left.\mathrm{ml}^{-1}\right]$. The DNA-DNA relatedness percentages presented are means based on at least two hybridization experiments. Reciprocal reactions (e.g. $\mathrm{AxB}$ and $\mathrm{BxA}$ ) were performed and the variation between them was within the limit of this method (Goris et al., 1998).

Colonies of all strains grown on TSA or Nutrient Agar (NA; Oxoid) were circular, convex, smooth and slightly opaque with entire margins. These colonies were notably smaller than those of the other described Acinetobacter species (Fig. 1). On NA, the colonies were $0 \cdot 1-0 \cdot 4 \mathrm{~mm}$ and $0.3-0.9 \mathrm{~mm}$ in diameter after 24 and $48 \mathrm{~h}$ incubation at $30^{\circ} \mathrm{C}$, respectively, while on TSA, the colonies were $0 \cdot 3-0.7 \mathrm{~mm}$ and $1.0-1.4 \mathrm{~mm}$ in diameter after 24 and $48 \mathrm{~h}$ of incubation at $30^{\circ} \mathrm{C}$, respectively. The use of other agar media including chocolate and blood agar did not significantly affect colony size as compared with TSA.

All strains grew in Brain-Heart Infusion (Difco) broth at temperatures ranging from 25 to $35^{\circ} \mathrm{C}$ but not at $41^{\circ} \mathrm{C}$. All but one strain (LMG 21766) grew at $37^{\circ} \mathrm{C}$, although the

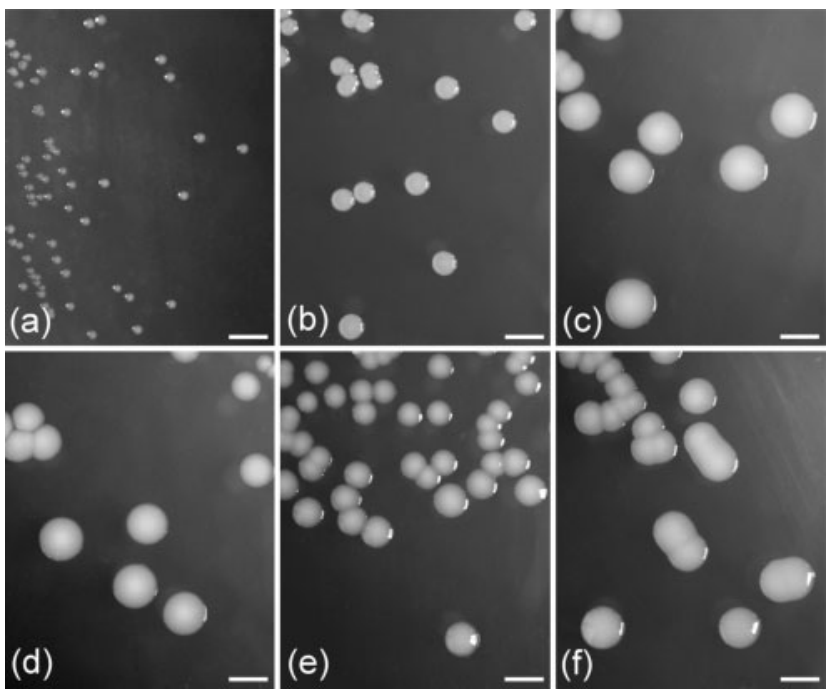

Fig. 1. Colonies of Acinetobacter parvus and the type strains of selected Acinetobacter species. (a) A. parvus LMG $21765^{\top}$; (b) Acinetobacter ursingii LUH $3792^{\mathrm{T}}$; (c) Acinetobacter Iwoffii ATCC $15309^{\top}$; (d) A. johnsonii ATCC $17909^{\top}$; (e) A. junii ATCC $17908^{\top}$; (f) Acinetobacter schindleri LUH $5832^{\top}$. The strains were grown on TSA at $30^{\circ} \mathrm{C}$ for $24 \mathrm{~h}$. Bars, $2 \mathrm{~mm}$.

growth of LUH 3067 and RUH 2008 was reduced at this temperature as compared to growth at $30^{\circ} \mathrm{C}$. All strains utilized ethanol and acetate as sole sources of carbon and energy and their growth on these two substrates was clear after 2 days incubation. All strains were negative in the following tests: acid production from D-glucose, haemolysis of sheep blood, gelatinase production, and the utilization of DL-lactate, DL-4-aminobutyrate, trans-aconitate, citrate (Simmons), glutarate, L-aspartate, azelate, $\beta$-alanine, Lhistidine, D-malate, malonate, histamine, L-phenylalanine, phenylacetate, levulinate, citraconate, 4-hydroxybenzoate, L-tartrate, L-ornithine, L-leucine, L-arabinose and 2,3butanediol.

The result of the comparative analysis of AFLP patterns of 


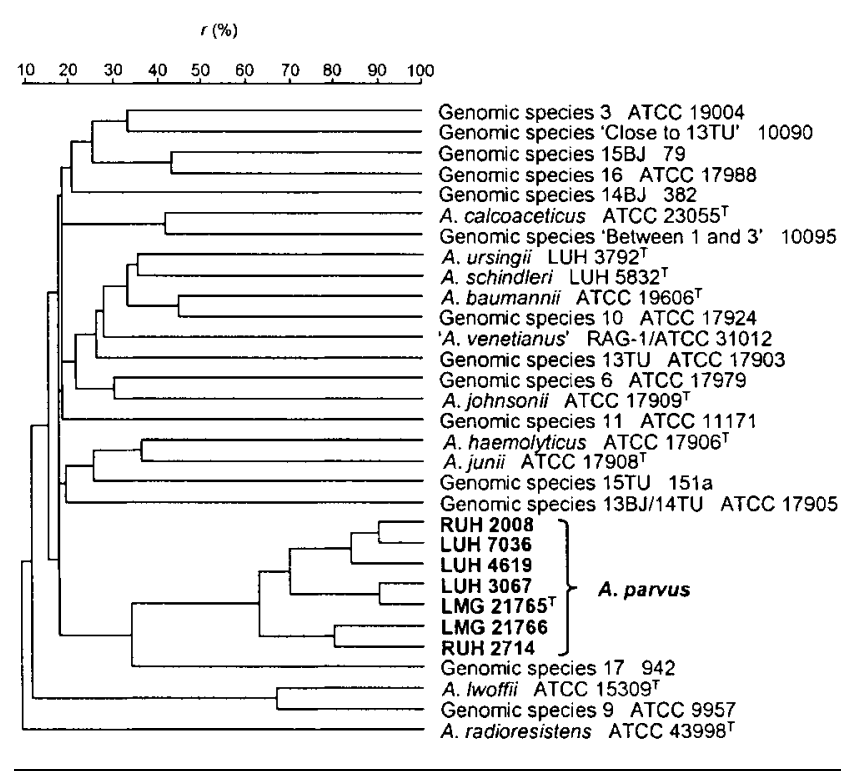

Fig. 2. Dendrogram of cluster analysis of AFLP fingerprints of seven strains of Acinetobacter parvus and 24 strains representing all known (genomic) species of the genus Acinetobacter. Fingerprints were generated using automated laser fluorescence detection and cluster analysis was performed with the BIONUMERICS software package (Applied Maths) using Pearson's product for similarity calculation and UPGMA for clustering (Nemec et al., 2001).

the seven strains and type and reference strains of all described Acinetobacter (genomic) species is shown in Fig. 2. The seven strains grouped at $63 \%$, which is well above the $50 \%$ level seen in previous studies for the delineation of Acinetobacter species (Nemec et al., 2001). They were clearly separated from the other Acinetobacter (genomic) species (each species represented by one strain) at $34 \%$.

The $16 \mathrm{~S}$ rDNA sequences of strains LMG $21765^{\mathrm{T}}$ and LMG 21766 (EMBL accession nos AJ293691 and AJ293690, respectively) showed $99 \cdot 8 \%$ similarity. The similarity values between these sequences and those of the other 24 (genomic) species of the genus Acinetobacter (EMBL accession nos Z93434-Z93454, AJ275038, AJ278311 and AJ295007) were in the range of $95 \cdot 9-98 \cdot 1 \%$, which corresponds to the interspecies similarity values of the genus Acinetobacter (Ibrahim et al., 1997; Nemec et al., 2001).

Structural homogeneity of $16 \mathrm{~S}$ rDNA was confirmed by ARDRA. All strains had identical or almost identical restriction patterns: CfoI 1 (LMG 21765 ${ }^{\mathrm{T}}$, LUH 3067, LMG 21766 and RUH 2714) or CfoI $1+5$ (RUH 2008, LUH 4619 and LUH 7036), AluI 2, MboI 1, RsaI 2 and MspI 3.

DNA-DNA relatedness was determined between LMG $21765^{\mathrm{T}}$, LMG 21766 and the type strains of the nomenspecies that had shown highest similarity $(>96.5 \%)$ of $16 \mathrm{~S}$ rDNA sequences with the two strains (Table 2). The level of
Table 2. DNA-DNA binding values (\%) between LMG $21765^{\top}$, LMG 21766 and strains of related Acinetobacter species

\begin{tabular}{|c|c|c|}
\hline Strain & LMG $21765^{\mathrm{T}}$ & LMG 21766 \\
\hline A. parvus LMG $21765^{\mathrm{T}}$ & 100 & 82 \\
\hline A. parvus LMG 21766 & 82 & 100 \\
\hline A. junii LMG $998^{\mathrm{T}}$ & 32 & 33 \\
\hline A. haemolyticus LMG $996^{\mathrm{T}}$ & 35 & 30 \\
\hline A. baumannii LMG $1041^{\mathrm{T}}$ & 21 & 20 \\
\hline A. johnsonii $\mathrm{LMG} 999^{\mathrm{T}}$ & 22 & 20 \\
\hline A. calcoaceticus $\mathrm{LMG} 1046^{\mathrm{T}}$ & 18 & 19 \\
\hline 'A. venetianus' LMG 19082/RAG-1 & 29 & 29 \\
\hline
\end{tabular}

DNA-DNA binding between LMG $21765^{\mathrm{T}}$ and LMG 21766 was $82 \%$. DNA-DNA binding values between these strains and the type strains of Acinetobacter junii, A. haemolyticus, A. baumannii, Acinetobacter johnsonii, A. calcoaceticus and the reference strain of ' $A$. venetianus' were not higher than $35 \%$. The DNA G $+\mathrm{C}$ content of LMG $21765^{\mathrm{T}}$ and LMG 21766 was $41 \cdot 8$ and $41 \cdot 5 \%$, respectively.

On the basis of phenotypic and genotypic characteristics, it is proposed that the seven small-colony-forming strains represent a hitherto unknown species of the genus Acinetobacter, for which the name Acinetobacter parvus is proposed.

A. parvus can be differentiated from other Acinetobacter (genomic) species by its negative results in biochemical tests suggested by Bouvet \& Grimont (1987), in particular by the inability to oxidize D-glucose, to hydrolyse gelatin and to utilize DL-lactate, DL-4-aminobutyrate, citrate (Simmons), azelate, $\beta$-alanine and L-histidine (Bouvet \& Grimont, 1987; Bouvet \& Jeanjean, 1989; Gerner-Smidt et al., 1991; Vaneechoutte et al., 1999; Nemec et al., 2001). The acetate utilization test which is positive in A. parvus is necessary to differentiate prototrophic $A$. parvus strains from auxotrophic strains of other Acinetobacter (genomic) species. Notably, its typical colony size is an important feature to recognize $A$. parvus amidst colonies of other species and genera, and to differentiate it from biochemically inactive strains of other Acinetobacter (genomic) species.

ARDRA allowed for differentiation of A. parvus from all described (genomic) species of Acinetobacter, except A. junii and proteolytic genomic species 17 (Dijkshoorn et al., 1998; Vaneechoutte et al., 1999; Nemec et al., 2001). Four A. parvus strains had the same ARDRA combination pattern (CfoI 1, AluI 2, MboI 1, RsaI 2, MspI 3) as the latter two (genomic) species. However, A. parvus strains can easily be distinguished from genomic species 17 and A. junii strains sharing this ARDRA profile by their small colonies and the inability to lyse sheep erythrocytes.

The A. parvus strains were isolated from human and animal non-sterile body sites, except for RUH 2008, which originated from the blood of a human. Isolation of this strain was 
followed by other isolates with similar characteristics from intravenous catheters, which indicates that the strain was involved in a catheter-related blood-stream infection. Strain LUH 7036 was isolated from the ear of a dog with refractory otitis media.

During this study, an additional strain (LUH 4826) that was phenotypically indistinguishable from the A. parvus strains was isolated from a human clinical specimen. However, LUH 4826 had AluI and RsaI ARDRA patterns different from those of the A. parvus strains and AFLP fingerprinting showed no significant similarity between this strain and any of the described Acinetobacter (genomic) species including A. parvus (not shown). Therefore, LUH 4826 may represent an as-yet-undescribed species of the genus Acinetobacter that is phenotypically similar to A. parvus. This finding demonstrates that, as is the case with most Acinetobacter (genomic) species, definitive species identification requires the use of genotypic methods.

\section{Description of Acinetobacter parvus sp. nov.}

Acinetobacter parvus (par'vus. L. masc. adj. parvus small, referring to the fact that its colonies on agar media are significantly smaller than those of the other known Acinetobacter species).

Characteristics correspond to those of the genus (Juni, 1984). The description is based on the characterization of seven strains of different origin. Colonies on TSA after $24 \mathrm{~h}$ incubation at $30^{\circ} \mathrm{C}$ are approximately $0.3-0.7 \mathrm{~mm}$ in diameter, circular, convex, smooth and slightly opaque with entire margins. Growth occurs at $35^{\circ} \mathrm{C}$ but not at $41{ }^{\circ} \mathrm{C}$. Growth at $37^{\circ} \mathrm{C}$ usually occurs but may be reduced. Good growth on ethanol and acetate as sole sources of carbon and energy. Negative results in the following tests: acid production from D-glucose, haemolysis of sheep blood, gelatinase production and the utilization of DL-lactate, DL-4aminobutyrate, trans-aconitate, citrate (Simmons), glutarate, L-aspartate, azelate, $\beta$-alanine, L-histidine, D-malate, malonate, histamine, L-phenylalanine, phenylacetate, levulinate, citraconate, 4-hydroxybenzoate, L-tartrate, Lornithine, L-leucine, L-arabinose and 2,3-butanediol.

The type strain is LMG $21765^{\mathrm{T}}$ ( $=\mathrm{LUH} 4616^{\mathrm{T}}=\mathrm{NIPH}$ $384^{\mathrm{T}}=$ CCM $\left.7030^{\mathrm{T}}\right)$. Isolated from the ear of an outpatient. This strain grows well at $37^{\circ} \mathrm{C}$ and has the following restriction patterns of amplified $16 \mathrm{~S}$ rDNA: $C f o \mathrm{I} 1, A l u \mathrm{I} 2$, MboI 1, RsaI 2, MspI 3. Its DNA G + C content is $41 \cdot 8 \%$.

\section{Acknowledgements}

We thank Dr A. T. Bernards (Leiden University Medical Center) and Dr J. Wagenaar (ID-Lelystad) for generous provision of strains.

\section{Note added in proof}

Since the study was completed, seven additional strains with typical $A$. parvus colonies have been studied in our laboratories. All of them were isolated from human clinical specimens (blood, ear pus, vaginal swab) and showed AFLP fingerprints, ARDRA profiles and biochemical properties typical of $A$. parvus. The only exception was the ability of three of these strains to grow on L-ornithine. Since this article was accepted for publication, seven new species of Acinetobacter have been described (Carr et al., 2003). Comparison of published 16S rDNA sequences and phenotypic characteristics did not show the identity of A. parvus with any of these species.

\section{References}

Bernards, A. T., de Beaufort, A. J., Dijkshoorn, L. \& van Boven, C. P. A. (1997). Outbreak of septicaemia in neonates caused by Acinetobacter junii investigated by amplified ribosomal DNA restriction analysis (ARDRA) and four typing methods. J Hosp Infect 35, 129-140.

Bouvet, P. J. M. \& Grimont, P. A. D. (1986). Taxonomy of the genus Acinetobacter with the recognition of Acinetobacter baumannii sp. nov., Acinetobacter haemolyticus sp. nov., Acinetobacter johnsonii sp. nov., and Acinetobacter junii sp. nov. and emended descriptions of Acinetobacter calcoaceticus and Acinetobacter lwoffii. Int J Syst Bacteriol 36, 228-240.

Bouvet, P. J. M. \& Grimont, P. A. D. (1987). Identification and biotyping of clinical isolates of Acinetobacter. Ann Inst Pasteur Microbiol 138, 569-578.

Bouvet, P. J. M. \& Jeanjean, S. (1989). Delineation of new proteolytic genomic species in the genus Acinetobacter. Res Microbiol 140, 291-299.

Carr, E. L., Kämpfer, P., Patel, B. K. C., Gürtler, V. \& Seviour, R. J. (2003). Seven novel species of Acinetobacter isolated from activated sludge. Int J Syst Evol Microbiol 53, 953-963.

Cruze, J. A., Singer, J. T. \& Finnerty, W. R. (1979). Conditions for quantitative transformation in Acinetobacter calcoaceticus. Curr Microbiol 3, 129-132.

Dijkshoorn, L., van Harsselaar, B., Tjernberg, I., Bouvet, P. J. M. \& Vaneechoutte, M. (1998). Evaluation of amplified ribosomal DNA restriction analysis for identification of Acinetobacter genomic species. Syst Appl Microbiol 21, 33-39.

Ezaki, T., Hashimoto, Y. \& Yabuuchi, E. (1989). Fluorometric deoxyribonucleic acid-deoxyribonucleic acid hybridization in microdilution wells as an alternative to membrane filter hybridization in which radioisotopes are used to determine genetic relatedness among bacterial strains. Int J Syst Bacteriol 39, 224-229.

Gerner-Smidt, P. \& Tjernberg, I. (1993). Acinetobacter in Denmark: II. Molecular studies of the Acinetobacter calcoaceticus-Acinetobacter baumannii complex. APMIS 101, 826-832.

Gerner-Smidt, P., Tjernberg, I. \& Ursing, J. (1991). Reliability of phenotypic tests for identification of Acinetobacter species. J Clin Microbiol 29, 277-282.

Goris, J., Suzuki, K., De Vos, P., Nakase, T. \& Kersters, K. (1998). Evaluation of a microplate DNA-DNA hybridization method compared with the initial renaturation method. Can J Microbiol 44, 1148-1153.

Ibrahim, A., Gerner-Smidt, P. \& Liesack, W. (1997). Phylogenetic relationship of the twenty-one DNA groups of the genus Acinetobacter as revealed by $16 \mathrm{~S}$ ribosomal DNA sequence analysis. Int J Syst Bacteriol 47, 837-841.

Juni, E. (1972). Interspecies transformation of Acinetobacter: genetic evidence for a ubiquitous genus. J Bacteriol 112, 917-931. 
Juni, E. (1984). Genus III. Acinetobacter Brisou and Prévot 1954, $727^{\mathrm{AL}}$. In Bergey's Manual of Systematic Bacteriology, vol. 1, pp. 303-307. Edited by N. R. Krieg \& J. G. Holt. Baltimore: Williams \& Wilkins.

Mesbah, M., Premachandran, U. \& Whitman, W. B. (1989). Precise measurement of the $\mathrm{G}+\mathrm{C}$ content of deoxyribonucleic acid by high-performance liquid chromatography. Int J Syst Bacteriol 39, 159-167.

Nemec, A., Dijkshoorn, L. \& Ježek, P. (2000). Recognition of two novel phenons of the genus Acinetobacter among non-glucoseacidifying isolates from human specimens. J Clin Microbiol 38, 3937-3941.

Nemec, A., De Baere, T., Tjernberg, I., Vaneechoutte, M., van der Reijden, T. J. K. \& Dijkshoorn, L. (2001). Acinetobacter ursingii sp. nov. and Acinetobacter schindleri sp. nov., isolated from human clinical specimens. Int J Syst Evol Microbiol 51, 1891-1899.
Tjernberg, I. \& Ursing, J. (1989). Clinical strains of Acinetobacter classified by DNA-DNA hybridization. APMIS 97, 595-605.

Vaneechoutte, M., Tjernberg, I., Baldi, F., Pepi, M., Fani, R., Sullivan, E. R., van der Toorn, J. \& Dijkshoorn, L. (1999). Oildegrading Acinetobacter strain RAG-1 and strains described as 'Acinetobacter venetianus sp. nov.' belong to the same genomic species. Res Microbiol 150, 69-73.

Willems, A., Doignon-Bourcier, F., Goris, J., Coopman, R., de Lajudie, P., De Vos, P. \& Gillis, M. (2001). DNA-DNA hybridization study of Bradyrhizobium strains. Int $J$ Syst Evol Microbiol 51, 1315-1322.

Wilson, K. (1987). Preparation of genomic DNA from bacteria. In Current Protocols in Molecular Biology, pp. 2.4.1-2.4.5. Edited by F. M. Ausubel, R. Brent, R. E. Kingston, D. D. Moore, J. G. Seidman, J. A. Smith \& K. Struhl. New York: Green Publishing and WileyInterscience. 